\title{
Proceeding
}

Supplementary Issue: Winter Conferences of Sports Science. Costa Blanca Sports Science Events, 24 April 2020. Alicante, Spain.

\section{Inclusive assessment in sitting volleyball}

\author{
ILARIA VISCIONE \\ University of Salerno, Italy
}

\begin{abstract}
The aim of this study has been shown that through specific trainings, disabled players practitioners the sitting volleyball, how much they manage to improve their own performances, approaching to the standard of the not disabled players. Data were collected during twelve trainings on specific task (test on the set, being sit). The subjects involved in the study, on the technical element of the set, are six players not disabled and six players disabled for a period of two months with a specific training, to verify the improvement of the two groups.
\end{abstract}

Keywords: Sitting volley; Disabled; Performance; Evaluation.

\section{Cite this article as:}

Viscione, I. (2020). Inclusive assessment in sitting volleyball. Journal of Human Sport and Exercise, 15(2proc), S261-S267. doi:https://doi.org/10.14198/jhse.2020.15.Proc2.17

\section{Corresponding author. University of Salerno, Italy.}

E-mail: gaetano.raiola2012@gmail.com

Supplementary Issue: Winter Conferences of Sports Science. Costa Blanca Sports Science Events, 24 April 2020. Alicante, Spain.

JOURNAL OF HUMAN SPORT \& EXERCISE ISSN 1988-5202

(c) Faculty of Education. University of Alicante

doi:10.14198/jhse.2020.15.Proc2.17 


\section{INTRODUCTION}

Sports activity plays a very important role in training and education (D'lsanto, 2016), for many it is an opportunity to keep both body and mind in training (Cassese \& Raiola, 2017). The disabled person can enter the world of sport, because he is seen as a subject who has the right to develop his physical-motor, intellectual and social skills (Ghirlanda, 2003). Continuity of physical activity and sport must be ensured throughout life, through permanent, global and democratized education, to encourage the full integration of each one within society (International Charter, 1978).

Sport allows the individual to improve physical qualities, to enhance cognitive and psychic aspects and to develop very valuable socio-relational skills, especially in the case of people with disabilities (Boccia et al., 2019). Sport allows the subject to achieve an improvement from a physical point of view but also contributes significantly to psychic and socio-relational aspects (Raiola et al., 2018). Today, people with disabilities, thanks to the introduction of specific adaptations, are guaranteed participation in physical education in schools and many of the most common sports (Sanseviero et al., 2019).

For people with special educational needs the Adapted Physical Activity (APA) is increasing and diversified, because it operates in a net dedicated both to disability that at people with needs and special needs (Sherrill \& Hutzler, 2010).

The original purpose of disability sports as rehabilitation through sports. The term "disability sports" refers to sports that have been designed for athletes with disabilities. Volleyball as a worldwide game practiced by able bodied athletes, has been modified and adapted to the level which allows athletes with disabilities to participate (Vute, 2009).

Sitting Volley is a Paralympic discipline, a variant of traditional volleyball, which is played by disabled athletes (Molik et al., 2008).

Sitting volleyball is a modification of the standing game: the net is lower, the court is smaller, the area of the body between the buttocks and the shoulders must be in contact with the floor, following a joust, the point is replayed and the service block is permitted ( $\mathrm{Ng}, 2012)$.

Shifts are one of the characterizing aspects of Sitting Volley. It is evident that the careful style and the ability to observe the various situations that take place in the opposing field are essential to provide the necessary inputs to intervene quickly and above all opportune. The ability to anticipate movement is therefore even more decisive in this fundamental for allow you to be ready under the ball as soon as possible.

In Sitting Volley there is no differentiation of skill levels as, on the other hand, exists in other disciplines (Gaetano, 2012;2015). Once seated on the ground, in fact, the different skills tend to level out, allowing athletes with quite different disabilities to coexist (Martino et al., 2019). It is for this reason also that within the sitting volleyball teams, disabled and able-bodied people can coexist, for promotional purposes, also expressing a good technical level, thus representing an important example of cooperation and above all of inclusion (Raiola, 2013; 2015). 


\section{METHODS}

Data were collected during two months on specific task, to assess the effectiveness of lateral, forward, and posterior direction on speed of movement, in the width of the volleyball court, of sitting-volleyball players and non-disabled players. The subjects involved in the study, on the technical element of the set, are six players not disabled and six players disabled for a period of two months with a specific training, to verify the improvement of the two groups.

Three types of movement were analysed for this study: forward, back, and side. The dependent variable for the tests was the time needed for a player to reach a distance. Timing began with the first movement of the hands and ended when it reached the set point.

\section{Statistical analysis}

A paired sample t-test was conducted to combine the results obtained from the test and re-test. The t-test was selected as the analytical method to verify the presence or absence of a significant difference between two sets of data. The significant level has been set at $p<.05$.

\section{RESULTS}

From what emerges from Table 1, and the correlated Figure 1, we can see that, in the disabled people, the record for frontal direction fluctuates between 4.8 seconds and 6.5 seconds (the average is 5.6 seconds). For the backward direction the record fluctuates between 4.9 seconds and 7.1 seconds (the average is 6.1 seconds).

In non-disabled people the record for frontal direction fluctuates between 4.9 seconds and 7.9 seconds (the average is 6.6 seconds). For the backward direction the record fluctuates between 5.6 seconds and 8.0 seconds (the average is 6.8 seconds).

From Table 2, and the correlated Figure 2, we can see that, in the disabled people, the record for frontal direction fluctuates between 3.9 seconds and 5.7 seconds (the average is 5.0 seconds). For the backward direction the record fluctuates between 4.0 seconds and 6.1 seconds (the average is 5.3 seconds).

In non-disabled people the record for frontal direction fluctuates between 4.1 seconds and 7.1 seconds (the average is 5.7 seconds). For the backward direction the record fluctuates between 4.7 seconds and 6.9 seconds (the average is 5.9 seconds).

Table 1. Before training.

\begin{tabular}{lcccc}
\hline \multirow{2}{*}{ Time (sec.) } & \multicolumn{2}{c}{ Disabled people } & \multicolumn{2}{c}{ Non-disabled people } \\
\cline { 2 - 5 } & Frontal direction & Backward direction & Frontal direction & Backward direction \\
\hline Player 1 & 5.3 & 5.4 & 6.3 & 6.6 \\
Player 2 & 4.8 & 4.9 & 4.9 & 5.6 \\
Player 3 & 5.3 & 5.7 & 5.9 & 6.8 \\
Player 4 & 6.2 & 6.4 & 7.2 & 7.1 \\
Player 5 & 5.5 & 6.9 & 7.3 & 6.9 \\
Player 6 & 6.5 & 7.1 & 7.9 & 8.0 \\
Average & 5.6 & 6.1 & 6.6 & 6.8 \\
\hline
\end{tabular}


Table 2. After training.

\begin{tabular}{lcccc}
\hline \multirow{2}{*}{ Time (sec.) } & \multicolumn{2}{c}{ Disabled people } & \multicolumn{2}{c}{ Non-disabled people } \\
\cline { 2 - 5 } & Frontal direction & Backward direction & Frontal direction & Backward direction \\
\hline Player 1 & 4.7 & 5.0 & 5.2 & 5.4 \\
Player 2 & 3.9 & 4.0 & 4.1 & 4.7 \\
Player 3 & 4.6 & 4.9 & 5.1 & 5.9 \\
Player 4 & 5.7 & 5.8 & 6.1 & 6.4 \\
Player 5 & 5.4 & 6.1 & 6.7 & 6.2 \\
Player 6 & 5.5 & 5.9 & 7.1 & 6.9 \\
Average & 5.0 & 5.3 & 5.7 & 5.9 \\
\hline
\end{tabular}

Table 3. T-test frontal direction with Disabled people.

\begin{tabular}{lll}
\hline & Frontal direction Before training & Frontal direction After training \\
\hline Mean & 5.6 & 4.966666667 \\
Variance & 0.4 & 0.470666667 \\
Observation & 6 & 6 \\
Pearson correlation & .885002521 & \\
$\mathrm{df}$ & 5 & \\
$\mathrm{t}$ stat & 4.841648319 & \\
$\mathrm{p}(\mathrm{T}<=\mathrm{t})$ one tail & .002354072 & \\
$\mathrm{t}$ critical one tail & 2.015048373 & \\
$\mathrm{p}(\mathrm{T}<=\mathrm{t})$ two tails & .004708144 & \\
$\mathrm{t}$ critical two tails & 2.570581836 & \\
\hline
\end{tabular}

Table 4. T-test backward direction with Disabled people.

\begin{tabular}{lll}
\hline & Backward direction Before training & Backward direction After training \\
\hline Mean & 6.066666667 & 5.283333333 \\
Variance & 0.762666667 & 0.637666667 \\
Observation & 6 & 6 \\
Pearson correlation & .951190669 & \\
df & 5 & \\
$t$ stat & 7.069467842 & \\
$\mathrm{p}(\mathrm{T}<=\mathrm{t})$ one tail & .000437994 & \\
$\mathrm{t}$ critical one tail & 2.015048373 & \\
$\mathrm{p}(\mathrm{T}<=\mathrm{t})$ two tails & .000875988 & \\
$\mathrm{t}$ critical two tails & 2.570581836 & \\
\hline
\end{tabular}

Table 5. T-test frontal direction with Non-disabled people.

\begin{tabular}{lll}
\hline & Frontal direction (1) & Frontal direction (2) \\
\hline Mean & 6.583333333 & 5.716666667 \\
Variance & 1.201666667 & 1.257666667 \\
Observation & 6 & 6 \\
Pearson correlation & .984532851 & \\
df & 5 & \\
$t$ stat & 10.79591238 & \\
$\mathrm{p}(\mathrm{T}<=\mathrm{t})$ one tail & $5.91371 \mathrm{E}-05$ &
\end{tabular}




\begin{tabular}{ll}
\hline $\mathrm{t}$ critical one tail & 2.015048373 \\
$\mathrm{p}(\mathrm{T}<=\mathrm{t})$ two tails & .000118274 \\
$\mathrm{t}$ critical two tails & 2.570581836 \\
\hline
\end{tabular}

Table 6. T-test backward direction with Non-disabled people.

\begin{tabular}{lll}
\hline & Backward direction (1) & Backward direction \\
\hline Mean & 6.833333333 & 5.916666667 \\
Variance & 0.602666667 & 0.605666667 \\
Observation & 6 & 6 \\
Pearson correlation & .965520217 & \\
$\mathrm{df}$ & 5 & \\
$\mathrm{t}$ stat & 11 & \\
$\mathrm{p}(\mathrm{T}<=\mathrm{t})$ one tail & $5.40261 \mathrm{E}-05$ & \\
$\mathrm{t}$ critical one tail & 2.015048373 & \\
$\mathrm{p}(\mathrm{T}<=\mathrm{t})$ two tails & .000108052 & \\
$\mathrm{t}$ critical two tails & 2.570581836 & \\
\hline
\end{tabular}

\section{DISCUSSION}

Data do not show significant differences between the average travel times for the players who used an anterior, posterior and lateral position of the hands.

The two months training, to assess the speed of movement, in the width of the volleyball court, show an improvement both for disabled people that non-disabled.

For disabled people, the frontal direction decreases from 5.6 seconds before training to 5.0 seconds after two months training, while the backward direction decreases from 6.1 seconds before training to 5.3 seconds after training.

For non-disabled people, the frontal direction decreases from 6.6 seconds before training to 5.7 seconds after two months training, while the backward direction decreases from 6.8 seconds before training to 5.9 seconds after training.

For disabled people the improvement is 0.6 seconds for frontal direction and 0.8 seconds for backward direction.

For non-disabled people the improvement is 0.9 seconds both for frontal direction and for backward direction.

\section{CONCLUSION}

The results show that the performance of disabled athletes has improved, with a specific training of two months, compared to that of able-bodied athletes who carried out technical-tactical training during the same period. This study also highlighted the inadequacy of the socio-economic context in support of sport for disabled people as well as the difficulty of private companies in meeting, not always for direct responsibility of the latter, the needs of disabled people. We have seen the enormous sacrifices that a disabled person is forced to face every day to carry out training, an activity that could also be useful to facilitate the development of socio-relational aspects. 
The aim of this study is to demonstrate that through specific trainings, disabled players practitioners the sitting volleyball, how much they manage to improve their own performances, approaching to the standard of the not disabled players. For both disabled and non-disabled people, the balance between muscle endurance, energy system efficiency, basic strength and training techniques are all related.

\section{REFERENCES}

Altavilla, G., Raiola, G. (2019). A brief review on physiological commitment in basketball: An interpretative key, Journal of Human Sport and Exercise, 14(Proc1), pp. S59-S65. https://doi.org/10.14198/ihse.2019.14.proc1.07

Boccia, S., Izzo, R., D'Elia, F., Fattore, S. (2019). A wheelchair by the overboard model: a technological instrument for disabled basketball players. Journal of Human Sport and Exercise, 14(Proc4): S1080S1086. https://doi.org/10.14198/ihse.2019.14.proc4.71

Carta Internazionale per l'Educazione fisica e lo Sport, 1978.

Cassese, F.P., Raiola, G. (2017). The importance of sport in disability management [Važnost sporta u upravljanju kod invaliditeta] Sport Science, 10, pp. 7-11.

Ceruso, R., Esposito, G., D'Elia, F. (2019). Analysis and evaluation of the qualitative aspects of the young players. Journal of Physical Education and Sport, 19, art. no. 266, pp. 1814-1819.

D'Elia, F., Raiola, G. (2019). Sport and Exercise Sciences Degrees in Italy: Comparison Between Online and Traditional Teaching Models, Communications in Computer and Information Science, 1091, pp. 209-216. https://doi.org/10.1007/978-3-030-31284-8_16

D'Isanto, T. (2016). Pedagogical value of the body and physical activity in childhood, Sport Science, 9,13-18.

D'Isanto, T., D'Elia, F., Raiola, G., Altavilla, G. (2019). Assessment of sport performance: Theoretical aspects and practical indications, Sport Mont, 17 (1), pp. 79-82.

D'Isanto, T., Altavilla, G., Raiola, G. (2017). Teaching method in volleyball service: Intensive and exenstive tools in cognitive and ecological approach. Journal of Physical Education and Sport, 17, art. no. 233, pp. 2222-2227.

Di Domenico, F., D'isanto, T., Raiola, G. (2019). Role of speed and agility in the effectiveness of motor performance, Journal of Physical Education and Sport, 19, art. no. 271, pp. 1836-1842.

Federici, A., Zumbo, F., Raiola, G. (2019). Use of chains as a means of intensifying the load in resistance training, Journal of Physical Education and Sport, 19, art. no. 68, pp. 466-472.

Gaetano, R. (2012). Didactics of volleyball into the educate program for coaches/trainers/technicians of Italian Federation of Volleyball (FIPAV) Journal of Physical Education and Sport, 12 (1), pp. 25-29.

Gaetano, R., Paloma, F.G., Gaetano, A. (2015). Anxiety in the youth physical and sport activity, Mediterranean Journal of Social Sciences, 6 (3), pp. 227-230. https://doi.org/10.5901/mjss.2015.v6n3s2p227

Ghirlanda, S. (2003). Sport per tutti, spazio ai disabili. Ed. Del Cerro.

Martino, L., Fonzo, E., Cassese, F.P., D'isanto, T. (2019). Principles of adaptation of the rules for disabled athletes for an inclusion sport, Journal of Human Sport and Exercise, 14 (Proc2), pp. S215-S220. https://doi.org/10.14198/ihse.2019.14.proc2.08

Molik, B., Kosmol, A., \& Skucas, K. (2008). Sport-specific and general sporting physical fitness of sitting volleyball athletes. Physiotherapy, 16(4), 68-75.

$\mathrm{Ng}, \mathrm{K}$. (2012). When sitting is not resting: Sitting volleyball. AuthorHouse.

Raiola, G. (2013). Body knowledge and motor skills, Knowledge Cultures, 1 (6), pp. 64-72.

Raiola, G. (2015). Inclusion in sport dance and self perception, Sport Science, 8, 99-102. 
Raiola, G., D'elia, F., Altavilla, G. (2018). Physical activity and sports sciences between European Research Council and academic disciplines in Italy. Journal of Human Sport and Exercise, 13(Proc2), pp. S283-S295. https://doi.org/10.14198/jhse.2018.13.proc2.13

Sanseviero, I., Cassese, F.P., Fonzo, E., Altavilla, G. D'Elia F. (2019). Study on the master's degree in sciences of sports evaluation and sport for disabled at the University of Salerno, Italy. Journal of Human Sport and Exercise, 14(Proc2): S239-S244. https://doi.org/10.14198/jhse.2019.14.proc2.12

Sherrill C., Hutzler Y., 2010, Adapted physical activity sciences. In J. Borms (Ed.), Directory of sport science. Berlin: ICSSPE/CIEPSS.

Viscione, I., Invernizzi, P.L., Raiola, G. (2019). Physical education in secondary higher school, Journal $\begin{array}{lllll}\text { of Human Sport and Exercise, } 14 \text { (Proc4), pp. S706-S712. } & \text {. }\end{array}$ https://doi.org/10.14198//hse.2019.14.proc4.31

Vute, R. (2009). Teaching and coaching volleyball for the disabled. Ljubljana: Fakulteta za šport. Poznam beţno, nikoli se nisem ukvarjal/az njo Imam nekaj izkušenj v igranju odbojke Sem bivši/a igralec/ka odbojke Treniram odbojko.

\section{(c) $(\mathrm{G})(\mathrm{EY}$}

This work is licensed under a Attribution-NonCommercial-NoDerivatives 4.0 International (CC BY-NC-ND 4.0). 